\title{
Growing and $\mathrm{X}$-ray diffraction pattern of single-crystal double phosphate $\mathrm{Li}_{2} \mathrm{Mn}\left(\mathrm{PO}_{3}\right)_{4}$
}

\author{
P.G.Nagorny ${ }^{1}$, N.S.Slobodyanik ${ }^{1}$, R.V.Lavrik ${ }^{2}$, T.I.Ushchapivska ${ }^{2}$ \\ ${ }^{1}$ Department of Inorganic Chemistry, T.Shevchenko National University \\ of Kyiv, 64/13 Volodymyrska St., 01601 Kyiv, Ukraine \\ ${ }^{2}$ National University of Life and Environmental Sciences of Ukraine, \\ 17 Heroyiv Oborony St., 03041 Kyiv, Ukraine
}

Received January 22, 2018

\begin{abstract}
Optimum conditions for the growing of single crystals of $\mathrm{Li}_{2} \mathrm{Mn}\left(\mathrm{PO}_{3}\right)_{4}$ compound have been selected. Complete X-ray diffraction analysis has been performed to study synthesized phosphate $\mathrm{Li}_{2} \mathrm{Mn}\left(\mathrm{PO}_{3}\right)_{4}$. According to its structure, the double phosphate belongs to the orthorhombic crystal system, space group Pnma; lattice parameters are the following: $a=$ 9.268(1), $b=9.421(1), c=10.088(1) \AA, V=880.9 \AA^{3}, Z=4, \rho_{\text {calc }}=2.901 \mathrm{~g} / \mathrm{cm}^{3}$. Structural features of the synthesized phosphate have been determined. The compound has been studied using DTA and IR spectroscopy techniques along with the complete elemental analysis.

Keywords: double phosphates, IR spectroscopy, XRD/RSA, single crystal growing, flux crystallization.

Подобраны оптимальные условия выращивания монокристаллов соединения $\mathrm{Li}_{2} \mathrm{Mn}\left(\mathrm{PO}_{3}\right)_{4}$. Проведено полное рентгеноструктурное исследование синтезированного фосфата $\mathrm{Li}_{2} \mathrm{Mn}\left(\mathrm{PO}_{3}\right)_{4}$. Структура двойного фосфата принадлежит к орторомбической сингонии, пр. гр. Pnma, параметры кристаллической решетки равны: $a=9,268(1)$, $\mathrm{b}=9,421(1), c=10,088(1) \AA, \quad V=880.9 \AA^{3}, Z=4, \rho_{\text {выч. }}=2,901 \mathrm{r} / \mathrm{cm}^{3}$. Установлены особенности строения синтезированного фосфата. Соединение исследовано методами: ДТА, ИК-спектроскопии, проведено ее полный элементный анализ.
\end{abstract}

Вирощування та PCA монокристалів подвійного фосфату $\mathrm{Li}_{2} \mathrm{Mn}\left(\mathrm{PO}_{3}\right)_{4}$. П.Г.Нагор ний, М.С.Слободяник, Р.В.Лаврик, Т.І.Ущапівська.

Підібрано оптимальні умови вирощування монокристалів сполуки $\mathrm{Li}_{2} \mathrm{Mn}\left(\mathrm{PO}_{3}\right)_{4}$.

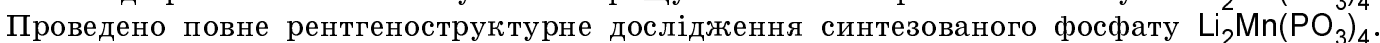
Структура подвійного фосфату належить до орторомбічної сингонії, пр. гр. Рnma, параметри кристалічної решітки дорівнюють: $a=9,268(1), \quad b=9,421(1), \quad c=$ $10,088(1) \AA, V=880,9 \AA^{3}, Z=4, \rho_{\text {вирах. }}=2,901$ г/см${ }^{3}$. Встановлені особливості будови синтезованого фосфату. Сполуку досліджено методами: ДТА, ІЧ-спектроскопії, проведено повний елементний аналіз.

\section{Introduction}

Phosphates of alkali and polyvalent metals exhibit a range of useful electrophysical properties, especially those phosphates that have corner-sharing octahedra of multivalent element in their structural framework. There is a series of phosphate compounds with the structure of well-known nonlinear optical crystal KTP $[1,2]$ and double polyphosphates of the $\mathrm{NaMn}\left(\mathrm{PO}_{3}\right)_{3}$ [3], $\mathrm{Cs}_{2} \mathrm{Mn}\left(\mathrm{PO}_{3}\right)_{4}$ [4] and $\mathrm{Rb}_{2} \mathrm{Mn}\left(\mathrm{PO}_{3}\right)_{4}$ type [5]. Investigations of properties of the compounds, synthesis of materials on their base attract the great scientific interest [6-9]. 
One of the most commonly used techniques of obtaining the double phosphates of alkali and $3 d$-metals is synthesis of the compounds from the fluxes of phosphate and fluoride phosphate systems of alkali metals by spontaneous crystallization with slow cooling $[10,11]$. Systems of $\mathrm{M}_{2} \mathrm{O}-$ $\mathrm{P}_{2} \mathrm{O}_{5}-\mathrm{Me}_{x} \mathrm{O}_{y}$-type (where $\mathrm{M}-\mathrm{Li}, \mathrm{Na}, \mathrm{K}$ ) are known to be not only universal solvents of $3 d$-metal oxides but also the reaction media for synthesis of the various double phosphates. This technique has certain advantages over the other methods and makes it possible to obtain (using programmable cooling) the substances in the form of highquality and high-purity crystals with high yield of interaction products [12, 13], which in turn has impact on physical and chemical properties of the synthesized substances.

The objective of this research is to determine the optimum conditions for synthesis of double poly-phosphate $\mathrm{Li}_{2} \mathrm{Mn}\left(\mathrm{PO}_{3}\right)_{4}$ and to study its physical and chemical properties.

\section{Experimental}

Interaction and solubility of mangan oxide (III) in the system $\mathrm{Li}_{2} \mathrm{O}-\mathrm{P}_{2} \mathrm{O}_{5}-\mathrm{Mn}_{2} \mathrm{O}_{3}$ were studied over the range of temperatures of $750-950^{\circ} \mathrm{C}$. Mole ratios of $\mathrm{Li}_{2} \mathrm{O}: \mathrm{P}_{2} \mathrm{O}_{5}$ were changed in the interval of 0.5 to 1.8 . Concentration of $\mathrm{Mn}_{2} \mathrm{O}_{3}$ in the initial fluxes of the system under study was changed over the range of $4.5-22.0$ wt. $\%$ wt.

The initial mixtures of $\mathrm{Li}_{2} \mathrm{O}-\mathrm{P}_{2} \mathrm{O}_{5}-\mathrm{Mn}_{2} \mathrm{O}_{3}$ system were prepared by mixing the calculated quantities of anhydrous reagents $\mathrm{LiPO}_{3}, \quad \mathrm{Li}_{4} \mathrm{P}_{2} \mathrm{O}_{7}$ and $\mathrm{NH}_{4} \mathrm{H}_{2} \mathrm{PO}_{4}$ (or $\left.\left(\mathrm{NH}_{4}\right)_{2} \mathrm{HPO}_{4}\right)$ with subsequent dehydration and melting at $750-800^{\circ} \mathrm{C} . \mathrm{Mn}_{2} \mathrm{O}_{3}$ was added to the fluxes with various $\mathrm{Li}_{2} \mathrm{O}: \mathrm{P}_{2} \mathrm{O}_{5}$ ratios followed by their flux at elevated temperatures in platinum crucibles for $2-4 \mathrm{~h}$ with intermittent mixing until homogeneity was obtained. The homogenous fluxes were kept at appropriate temperatures for 78 huntil establishment of equilibrium between the liquid and crystal phases.

The phase equilibriums were studied using visual-polythermal method. The equilibrium liquid phases were separated from the crystal ones by decantation with washing out from the residue flux using diluted solutions of mineral acids. The solid phases were identified using quantitative chemical and physicochemical methods of analysis. The content of mangan oxide (III) was determined in the decanted equilibrium liquid phases.

The contents of $\mathrm{Mn}_{2} \mathrm{O}_{3}$ in the equilibrium liquid phases of $\mathrm{Li}_{2} \mathrm{O}-\mathrm{P}_{2} \mathrm{O}_{5}-\mathrm{Mn}_{2} \mathrm{O}_{3}$ system

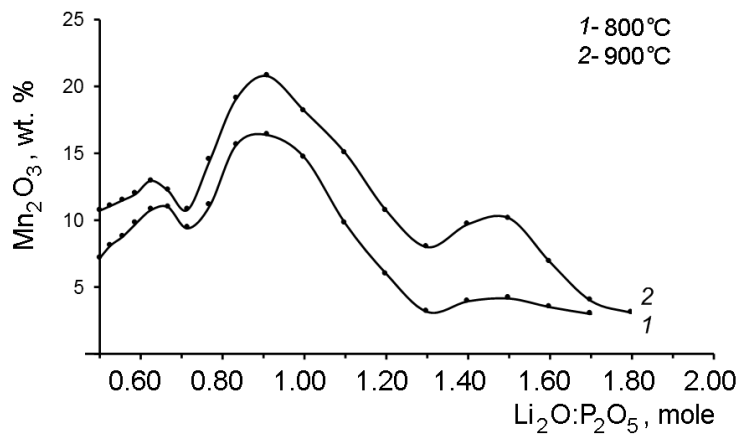

Fig. 1. Solubility isotherms of $\mathrm{Mn}_{2} \mathrm{O}_{3}$ in $\mathrm{Li}_{2} \mathrm{O}-\mathrm{P}_{2} \mathrm{O}_{5}-\mathrm{Mn}_{2} \mathrm{O}_{3}$ system.

with various mole ratios of $\mathrm{Li}_{2} \mathrm{O}: \mathrm{P}_{2} \mathrm{O}_{5}$ at $800^{\circ}$ and $900^{\circ} \mathrm{C}$ are given in Fig. 1. The solubility curves of mangan oxide (III) demonstrate several distinct extrema indicative of complex chemical interaction within the system. The maximum solubility of $\mathrm{Mn}_{2} \mathrm{O}_{3}$ in $\mathrm{Li}_{2} \mathrm{O}-\mathrm{P}_{2} \mathrm{O}_{5}-\mathrm{Mn}_{2} \mathrm{O}_{3}$ system is 20.80 wt.\% for the flux with the $\mathrm{Li}_{2} \mathrm{O}: \mathrm{P}_{2} \mathrm{O}_{5}$ mole ratio of 0.91 .

The fluxes with the mass of $8 \mathrm{~g}$ and $\mathrm{Li} 2 \mathrm{O}: \mathrm{P}_{2} \mathrm{O}_{5}$ molar ratio of 0.5 were saturated with mangan oxide (III) (1.4-2.0 g) at $900^{\circ} \mathrm{C}$ and homogenized for $3-4 \mathrm{~h}$. With gradual lowering of temperature from $900^{\circ} \mathrm{C}$ to $700^{\circ} \mathrm{C}$, single crystals of $\mathrm{Li}_{2} \mathrm{Mn}\left(\mathrm{PO}_{3}\right)_{4}$ were obtained from the fluxes within $24 \mathrm{~h}$, washed free from the flux residues using the diluted hydrochloric acid solution and washed out with water and dried at the room temperature. White crystals $0.5-2 \mathrm{~mm}$ in size were obtained.

The crystalline structure of novel double tetrametaphosphate $\mathrm{Li} 2 \mathrm{Mn}\left(\mathrm{PO}_{3}\right)_{4}$ was determined using X-ray diffraction method. X-ray diffraction analysis of the white crystals with rhomboidal habit having size of $0.2 \times 0.019 \times 0.2 \mathrm{~mm}^{3}$ was performed using Siemens P3/PC diffractometer under molybdenum radiation with graphite monochromator.

As a result of the experiment, 835 reflections (within $0 \leq h \leq 11 ; 0 \leq k \leq 11 ;-12 \leq l \leq 0$ ) were obtained, of which 696 independent reflections with $F>4 \delta$ (I) were used for calculations. The integrated intensity was measured using 2 $\theta: \theta$ method over the range of angles $5.92^{\circ} \leq \theta \leq 50.92^{\circ}$ at scan rate of $2-$ 18 degrees per minute. Crystalline lattice parameters were refined according to 64 reflections within the range of angles $18.0^{\circ} \leq \theta \leq 36.0^{\circ}$. 
Table 1. Results of chemical analysis of synthesized compounds (wt.\%)

\begin{tabular}{|c|c|c|c|c|c|c||}
\hline \multirow{2}{*}{$\begin{array}{c}\text { Formula } \\
\text { of compound }\end{array}$} & \multicolumn{2}{|c|}{$\mathrm{Li}_{2} \mathrm{O}$} & \multicolumn{2}{c||}{$\mathrm{P}_{2} \mathrm{O}_{5}$} \\
\cline { 2 - 7 } & calc. & obtained & calc. & obtained & calc. & obtained \\
\hline $\mathrm{Li}_{2} \mathrm{Mn}\left(\mathrm{PO}_{3}\right)_{4}$ & 7.80 & 7.77 & 18.44 & 18.48 & 73.76 & 73.75 \\
\hline
\end{tabular}

\section{Results and discussion}

When comparing the content of $\mathrm{Mn}_{2} \mathrm{O}_{3}$ in equilibrium liquid phases of the studied system at $800^{\circ} \mathrm{C}$ and $900^{\circ} \mathrm{C}$, a decrease in the solubility of mangan oxide (III) with larger molar ratios of $\mathrm{Li}_{2} \mathrm{O}: \mathrm{P}_{2} \mathrm{O}_{5}(1.1-1.8)$ can be observed.

According to the chemical analysis of solid phases formed during the crystallization of homogeneous fluxes with various $\mathrm{Li}_{2} \mathrm{O}: \mathrm{P}_{2} \mathrm{O}_{5}$ ratios, the following compounds are isolated: double phosphate $\mathrm{Li}_{2} \mathrm{Mn}\left(\mathrm{PO}_{3}\right)_{4}$ within the $\mathrm{Li}_{2} \mathrm{O}: \mathrm{P}_{2} \mathrm{O}_{5}$ mole ratios ranging from 0.5 to 0.76 ; diphosphates $\beta-\mathrm{Mn}_{2} \mathrm{P}_{2} \mathrm{O}_{7}$ and $\mathrm{Mn}_{2} \mathrm{P}_{2} \mathrm{O}_{7}$ crystallizing within the $\mathrm{Li}_{2} \mathrm{O}: \mathrm{P}_{2} \mathrm{O}_{5}$ mole ratios ranging from 0.76 to 1.3 and from 1.3 to 1.8 , respectively. The crystals of double phosphate $\mathrm{Li}_{2} \mathrm{Mn}\left(\mathrm{PO}_{3}\right)_{4}$ in the studied fluxes of $\mathrm{Li}_{2} \mathrm{O}-\mathrm{P}_{2} \mathrm{O}_{5}-\mathrm{Mn}_{2} \mathrm{O}_{3}$ system have been obtained for the first time ever.

Optimum conditions for the growing of single crystals of $\mathrm{Li} 2 \mathrm{Mn}\left(\mathrm{PO}_{3}\right)_{4}$ compound have been selected. The composition of synthesized compound $\mathrm{Li}_{2} \mathrm{Mn}\left(\mathrm{PO}_{3}\right)_{4}$ is supported by complete chemical analysis (Table 1 ).

Figure 2 demonstrates infrared spectrum of the double tetrametaphosphate $\mathrm{Li}_{2} \mathrm{Mn}\left(\mathrm{PO}_{3}\right)_{4}$. Infrared spectra of $\mathrm{Li}_{2} \mathrm{Mn}\left(\mathrm{PO}_{3}\right)_{4}$ were studied using spectrophotometers UR20 and UR-10 (Carl Zeiss) in the KBr tablets. The characteristic stretching bands $\tau$ $\left(\mathrm{PO}_{3}\right)-470,500 \mathrm{~cm}^{-1} ; \delta_{s}, \delta_{a s}(\mathrm{P}-\mathrm{O})+v$ (MO) - 570, 580, $590 \mathrm{~cm}^{-1} ; v_{s}(\mathrm{P}-\mathrm{O}-\mathrm{P})-$ $720,800 \mathrm{~cm}^{-1}$ and $v_{a s}(\mathrm{P}-\mathrm{O}-\mathrm{P})-920 \mathrm{~cm}^{-1}$ correspond to and are typical for the polyphosphates of $\mathrm{NaMn}\left(\mathrm{PO}_{3}\right)_{3}[3], \mathrm{Cs}_{2} \mathrm{Mn}\left(\mathrm{PO}_{3}\right)_{4}$ [4] and $\mathrm{Rb}_{2} \mathrm{Mn}\left(\mathrm{PO}_{3}\right)_{4}$ type [5]. The intrinsic oscillations of $v_{s} \mathrm{P}-\mathrm{O}-\mathrm{P}$ observed in the region of $700-800 \mathrm{~cm}^{-1}$ are indicative of the presence of polyphosphate chains of tetrahedra $\left[\mathrm{PO}_{4}\right]$ in the structure of the double phosphate $\mathrm{Li}_{2} \mathrm{Mn}\left(\mathrm{PO}_{3}\right)_{4}$.

Thermal tests were performed with derivatograph Q-1500 (Hungary). The sample was heated at the temperature range of 20$900^{\circ} \mathrm{C}$ under dynamic temperature elevation mode using cylindrical platinum crucibles (the sample weight: $0.300 \mathrm{~g}$; heating rate: $5 \mathrm{deg} / \mathrm{min}^{-1}$. The derivatographic analyses
Table 2. Coordinates of atoms $\left(\times 10^{4}\right)$ and equivalent thermal corrections $\left(\AA^{2} \times 10^{3}\right)$ for the $\mathrm{Li}_{2} \mathrm{Mn}\left(\mathrm{PO}_{3}\right)_{4}$ structure

\begin{tabular}{|c|c|c|c|c||}
\hline Atom & $x / a$ & $y / b$ & $z / c$ & $U_{e q}$ \\
\hline $\mathrm{Mn}(1)$ & $9876(1)$ & 7500 & $3031(1)$ & $9(1)$ \\
$\mathrm{P}(1)$ & $6946(1)$ & 7500 & $6070(1)$ & $8(1)$ \\
$\mathrm{P}(2)$ & $7078(1)$ & $9625(1)$ & $3896(1)$ & $8(1)$ \\
$\mathrm{P}(3)$ & $7270(1)$ & 12500 & $5157(1)$ & $7(1)$ \\
$\mathrm{O}(1)$ & $8501(3)$ & 7500 & $6252(3)$ & $15(1)$ \\
\hline
\end{tabular}

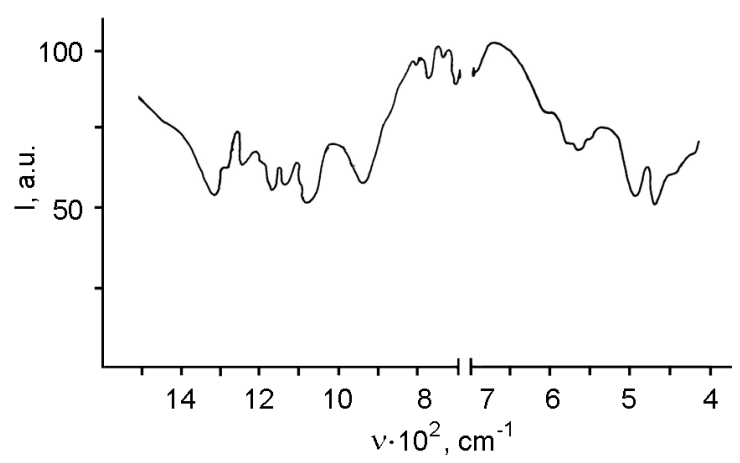

Fig. 2. Infrared spectrum of double phosphate $\mathrm{Li}_{2} \mathrm{Mn}\left(\mathrm{PO}_{3}\right)_{4}$.

shows that the double phosphate $\mathrm{Li}_{2} \mathrm{Mn}\left(\mathrm{PO}_{3}\right)_{4}$ is subject to congruent melting at the temperature of $760^{\circ} \mathrm{C}$.

According to its structure, $\mathrm{Li}_{2} \mathrm{Mn}\left(\mathrm{PO}_{3}\right)_{4}$ belongs to the orthorhombic crystal system, space group $P n m a$, lattice parameters are the following: $a=9.268(1), b=9.421(1)$, $c=10.088(1) \AA, V=880.9 \AA^{3}, Z=4, \rho_{\text {calc. }}=$ $2.901 \mathrm{~g} / \mathrm{cm}^{3}$.

The Lorenz factor correction and empirical absorption correction were applied to the dataset. The structure of $\mathrm{Li}_{2} \mathrm{Mn}\left(\mathrm{PO}_{3}\right)_{4}$ was calculated with anisotropic approximation of thermal parameters for all of the atoms. The final value of the divergence factor is $R_{w}=0.0676$ [14]. The positional parameters of atoms with the standard deviations are given in Table 2 .

Figure 3 demonstrates the projection of $\mathrm{Li}_{2} \mathrm{Mn}\left(\mathrm{PO}_{3}\right)_{4}$ structure on $x y$ plane. The double tetrametaphosphate structure is composed of nearly regular octahedra $\left[\mathrm{MnO}_{6}\right]$ and tetrahedra $\left[\mathrm{PO}_{4}\right]$. Three structurally 


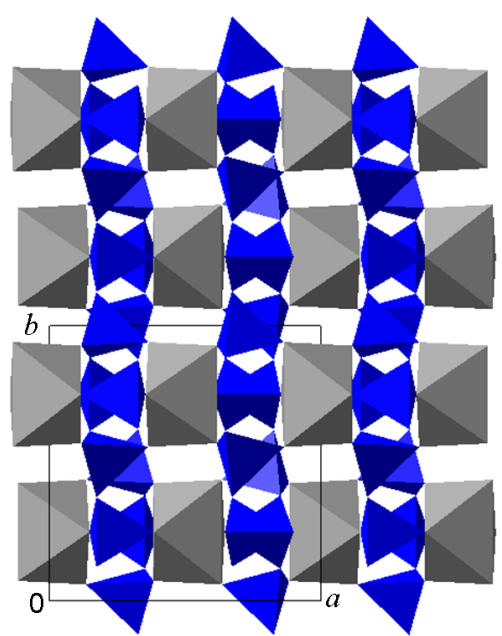

Fig. 3. Projection of $\mathrm{Li}_{2} \mathrm{Mn}\left(\mathrm{PO}_{3}\right)_{4}$ structure on $x y$ plane.

different phosphorus-oxygen tetrahedra are linked into polyphosphate chains $\left(\mathrm{PO}_{3}\right)$ that run along ob direction and divide the series of octahedra $\left[\mathrm{MnO}_{6}\right]$. Thus, the series of octahedra and chains $\left(\mathrm{PO}_{3}\right)$ run alternately along $o b$ direction in the structure of $\mathrm{Li}_{2} \mathrm{Mn}\left(\mathrm{PO}_{3}\right)_{4}$.

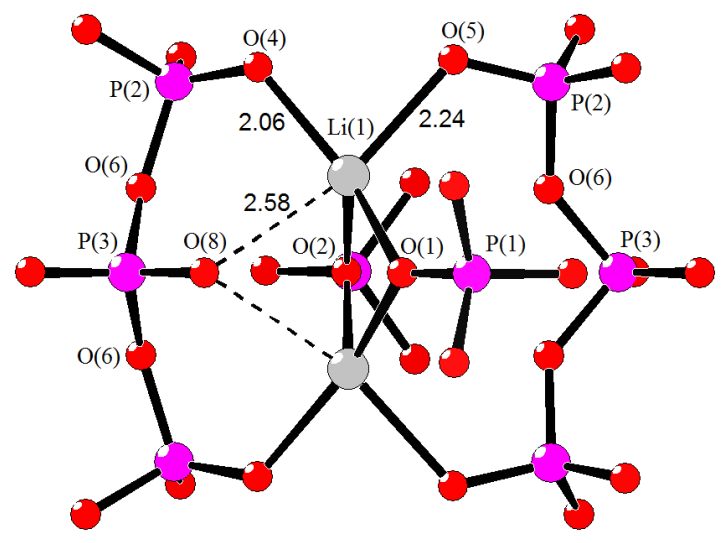

Fig. 4. Coordination environment of lithium atoms in $\mathrm{Li}_{2} \mathrm{Mn}\left(\mathrm{PO}_{3}\right)_{4}$ structure.

Each polyhedron $\left[\mathrm{MnO}_{6}\right]$ has two similar links $\mathrm{Mn}-\mathrm{O}(4)$ and $\mathrm{Mn}-\mathrm{O}(5) 2.261 \AA$ and $2.198 \AA$ long, respectively (see Table 3 ). All atoms of oxygen of the $\left[\mathrm{MnO}_{6}\right]$ octahedra contact four tetrahedra $\mathrm{P}(2) \mathrm{O}_{4}$ through $\mathrm{O}(5)$ and $\mathrm{O}(4)$ atoms and polyhedra $\mathrm{P}(1) \mathrm{O}_{4}$ and $\mathrm{P}(3) \mathrm{O}_{4}$ through $\mathrm{O}(7)$ and $\mathrm{O}(8)$ atoms, respectively. This combination of structure fragments results in the "pulling out" of octahe-

Table 3. Lengths of bonds $(\AA)$ in $\mathrm{Li}_{2} \mathrm{Mn}_{2}\left(\mathrm{PO}_{3}\right)_{4}$ structure

\begin{tabular}{|c|c|c|c|}
\hline Distance & $\AA$ & Distance & $\AA$ \\
\hline $\mathrm{Mn}(1)-\mathrm{O}(7) \# 2$ & $2.064(3)$ & $\mathrm{Mn}(1)-\mathrm{O}(8) \# 5$ & $2.136(3)$ \\
$\mathrm{Mn}(1)-\mathrm{O}(5) \# 6$ & $2.198(2)$ & $\mathrm{Mn}(1)-\mathrm{O}(5) \# 4$ & $2.198(2)$ \\
$\mathrm{Mn}(1)-\mathrm{O}(4) \# 7$ & $2.261(2)$ & $\mathrm{Mn}(1)-\mathrm{O}(4)$ & $2.261(2)$ \\
$\mathrm{Mn}(1)-\mathrm{Li}(1) \# 5$ & $3.349(6)$ & $\mathrm{Mn}(1)-\mathrm{Li}(1) \# 3$ & $3.349(6)$ \\
$\mathrm{P}(1)-\mathrm{O}(1)$ & $1.453(3)$ & $\mathrm{P}(1)-\mathrm{O}(2)$ & $1.468(3)$ \\
$\mathrm{P}(1)-\mathrm{O}(3) \# 7$ & $1.606(2)$ & $\mathrm{P}(1)-\mathrm{O}(3)$ & $1.606(2)$ \\
$\mathrm{P}(2)-\mathrm{O}(4)$ & $1.474(2)$ & $\mathrm{P}(2)-\mathrm{O}(5)$ & $1.476(2)$ \\
$\mathrm{P}(2)-\mathrm{O}(6)$ & $1.590(2)$ & $\mathrm{P}(2)-\mathrm{O}(3)$ & $1.591(2)$ \\
$\mathrm{P}(2)-\mathrm{Li}(1) \# 5$ & $3.097(6)$ & $\mathrm{P}(3)-\mathrm{O}(7)$ & $1.456(3)$ \\
$\mathrm{P}(3)-\mathrm{O}(8)$ & $1.472(3)$ & $\mathrm{P}(3)-\mathrm{O}(6)$ & $1.594(2)$ \\
$\mathrm{P}(3)-\mathrm{O}(6) \# 7$ & $1.594(2)$ & $\mathrm{O}(1)-\mathrm{Li}(1)$ & $1.983(6)$ \\
$\mathrm{O}(1)-\mathrm{Li}(1) \# 7$ & $1.983(6)$ & $\mathrm{O}(2)-\mathrm{Li}(1) \# 6$ & $2.002(6)$ \\
$\mathrm{O}(2)-\mathrm{Li}(1) \# 4$ & $2.002(6)$ & $\mathrm{O}(4)-\mathrm{Li}(1) \# 5$ & $2.059(6)$ \\
$\mathrm{O}(5)-\mathrm{Mn}(1) \# 6$ & $2.198(2)$ & $\mathrm{O}(5)-\mathrm{Li}(1) \# 2$ & $2.239(8)$ \\
$\mathrm{O}(7)-\mathrm{Mn}(1) \# 2$ & $2.064(3)$ & $\mathrm{O}(8)-\mathrm{Mn}(1) \# 5$ & $2.136(3)$ \\
$\mathrm{O}(8)-\mathrm{Li}(1) \# 5$ & $2.583(8)$ & $\mathrm{O}(8)-\mathrm{Li}(1) \# 3$ & $2.583(8)$ \\
$\mathrm{Li}(1)-\mathrm{O}(2) \# 6$ & $2.002(6)$ & $\mathrm{Li}(1)-\mathrm{O}(4) \# 5$ & $2.059(6)$ \\
$\mathrm{Li}(1)-\mathrm{O}(5) \# 2$ & $2.239(8)$ & $\mathrm{Li}(1)-\mathrm{O}(8) \# 5$ & $2.583(8)$ \\
$\mathrm{Li}(1)-\mathrm{Li}(1) \# 7$ & $2.760(1)$ & $\mathrm{Li}(1)-\mathrm{P}(2) \# 5$ & $3.097(6)$ \\
$\mathrm{Li}(1)-\mathrm{Mn}(1) \# 5$ & $3.349(6)$ & & \\
\hline \hline
\end{tabular}

$\# 1 x, y, z ; \# 2-x+1 / 2,-y, z+1 / 2 ; \# 3-x, y+1 / 2,-z ; \# 4 x+1 / 2,-y+1 / 2,-z+1 ; \# 5-x,-y,-z ; \# 6$ $x-1 / 2, y,-z-1 / 2 ; \# 7 x,-y-1 / 2, z ; \# 8-x-1 / 2, y-1 / 2, z-1 / 2$ 
dra from tetrahedra $\left[\mathrm{PO}_{4}\right]$ by polyphosphate chains and formation of rigid framework of the $\mathrm{Li}_{2} \mathrm{Mn}\left(\mathrm{PO}_{3}\right)_{4}$ structure.

Two figure-of-eight voids between tetrahedra $\left[\mathrm{PO}_{4}\right]$ have four symmetrical polyhedra of lithium. Lithium atoms occupy the same crystallographic position and have face-sharing contact formed by $\mathrm{O}(8), \mathrm{O}(2)$ and $\mathrm{O}(1)$ atoms (see Fig. 4) in the $\mathrm{Li}_{2} \mathrm{Mn}\left(\mathrm{PO}_{3}\right)_{4}$ structure. Four $\mathrm{Li}-\mathrm{O}$ bonds in the lithium polyhedra lie in the range of 1.983-2.239 $\AA$, and the fifth $\mathrm{Li}-\mathrm{O}(8)$ bond is a bit longer - its length is $2.583 \AA$. This suggests that the coordination number of lithium atoms is 5. Two lithium polyhedra are located between two polyphosphate chains composed of the tetrahedra $\mathrm{P}(2) \mathrm{O}_{4}$ and $\mathrm{P}(3) \mathrm{O}_{4}$. Thus, the five-vertex $\left[\mathrm{LiO}_{5}\right]$ are "clamped" between polyphosphate chains, which enhances the stiffness of the $\mathrm{Li}_{2} \mathrm{Mn}\left(\mathrm{PO}_{3}\right)_{4}$ structure.

\section{Conclusions}

The crystallization range of the new double phosphate $\mathrm{Li}_{2} \mathrm{Mn}\left(\mathrm{PO}_{3}\right)_{4}$ has been determined in the melts of $\mathrm{Li}_{2} \mathrm{O}-\mathrm{P}_{2} \mathrm{O}_{5}-\mathrm{Mn}_{2} \mathrm{O}_{3}$ system at the temperature range of $700-900^{\circ} \mathrm{C}$ '. Furthermore, the optimum conditions for growing of single-crystals of the compound with the high yield (over $50 \%$ of weight) have been selected, the series of their physical and chemical properties have been studied and the melting point of the compound has been determined. The complete XRD of the synthesized phosphate $\mathrm{Li}_{2} \mathrm{Mn}\left(\mathrm{PO}_{3}\right)_{4}$ has been performed and the special features of its structure have been defined: unusual co- ordination number of lithium atoms (5), recurrence interval of tetrahedra $\left[\mathrm{PO}_{4}\right]$ in the polyphosphate chains of the structure is 12 . These results stimulate further research of the compound and creation of the new materials on its basis.

\section{References}

1. N.V.Stus, P.G.Nagornyj, N.S.Slobodyanik, Ukr. Khim.Zh., 66, 72 (2000).

2. P.Urenski, G.Rosenman, J.Mater.Res., 16, 1493 (2001).

3. N.N.Chudinova, V.Murashova, B.S.Zaharova, J.Inorg. Chem., 43, 885 (1998).

4. B.Klinkert, M.Jansen, Z.Anorg.Allg.Chem., 570, 102 (1989).

5. V.Murashova, N.N.Chudinova, Inorg. Mater., 10, 1019 (1998).

6. I.V.Zatovsky, N.S.Slobodyanik, T.I.Uschapivska et al., Functional Materials, 24, 298 (2017).

7. I.V.Zatovsky, N.S.Slobodyanik, V.I.Ivanenko et al., Cryst.Res.\&Tech., 51, 178 (2015).

8. K.L.Kasthuri, P.B.Raghavendra, C.K.Subramanian, J.Solid State Chem., 3, 41 (1994).

9. T.A.William, L.F.Harrison, M.Phillips, Chem. Mater., No.11, 3555 (1999).

10. R.V.Lavrik, P.G.Nagornyj, N.S.Slobodyanik, Ukr. Khim.Zh.,72, 22 (2006).

11. P.G.Nagornyj, R.V.Lavrik, O.V.Petrenko, Ukr. Khim.Zh., 68, 25 (2002).

12. P.G.Nagornyj, R.V.Lavrik, A.O.Lubchenko, in: Abstr. IX Ukr. Conf. Mod. Prob. Chem., Kyiv, Ukraine (2008), p.36.

13. R.V.Lavrik, Visnik UNU, Chemistry, 20, 124 (2008).

14. G.M.Sheldrick, SHELX-97. A Progr. for Cryst. Structure. Ref, University of Goettingen, Germany (1997). 